\section{A ONU e os medicamentos}

\section{ONU and medicines}

A Organização das Nações Unidas (ONU) acaba de assumir uma decisão histórica, ao declarar que o acesso aos medicamentos deve constituir um direito humano, acima, portanto, da doutrina e das normas que dominam os mercados, agora, franqueados pelo laissez-faire do liberalismo econômico triunfante no mundo.

Antes mesmo da questão dos medicamentos em si, cabe uma rápida meditação sobre os limites éticos do próprio exercício dos processos e atividades econômicas. O livre arbítrio, a falsa iconografia que confere valores supremos à lei de oferta e procura na produção e trânsito de bens e serviços representa uma simplificação de relações e direitos sociais e humanos que não podem ser banalizados como ideais de convivência e de desenvolvimento da sociedade.

Uma rápida resenha histórica evidencia a falácia do mercado apriorístico. O taoísmo, muitos séculos antes de Cristo, já propunha um caminho de equilíbrio entre os homens e seus interesses e a natureza e suas leis. A ética e a política ocuparam os grandes momentos de reflexão de um dos maiores pensadores de todos os tempos, Aristóteles. O cristianismo, há dois milênios, incorporou a questão da virtude e da justiça no centro do debate ético. Esta postura se renovou, doutrinariamente, com a escolástica de São Tomás de Aquino e se atualizou, em nosso século, com as encíclicas dos papas, notadamente João XXIII e Paulo VI. Como processo político, o fim do feudalismo, a revolução francesa e a revolução russa ilustram, de forma marcante, a pertinência e consistência de idéias que contemplam a saga do homem dentro de uma perspectiva em que os valores individuais e grupais não podem ser hegemônicos em relação aos interesses maiores da coletividade. É este o preceito consagrado no pensamento mais atual (década de 90) como em Amathia Sen, prêmio Nobel de economia, e Viviane Forrestier, ensaísta de Le Monde e autora do best-seller "O horror econômico", tematizando a ditadura do lucro imposta pela economia liberal.

$\mathrm{O}$ século $\mathrm{XX}$ incorpora o direito à saúde, em di-

\section{Malaquias Batista Filho 1}

1 Departamento de Nutrição, Centro de Ciências da Saúde da Universidade Federal de Pernambuco, Campus Universitário, Cidade Universitária, Recife, Pernambuco, Brasil, CEP 50.070900

versas convenções internacionais, como um atributo necessário do conceito de cidadania. Desde a década de 20, a mulher, a criança e, por fim, todos os homens passaram a ser universalmente contemplados como beneficiários efetivos de bens e serviços básicos que possibilitem a vida com um mínimo de condições materiais de existência e dignidade. Mas foi na década de 90 que estes direitos passaram a se consubstanciar numa obrigação programática, com a Reunião de Cúpula de Nova York sobre a sobrevivência e o desenvolvimento das crianças e suas guardiãs imediatas - as mães de todo o mundo.

É uma etapa singular na evolução dos direitos humanos, que implicam em obrigações correlatas do estado e da sociedade. E é óbvio que, para o cumprimento desse desiderato hierárquico na escala de valores políticos e sociais, se inscreve a questão crucial dos medicamentos, já postulada há quase 23 anos, quando as Nações Unidas estabeleceram os compromissos da meta "Saúde para todos no ano 2000".

Convertida em mercadoria comum, tendo em sua cadeia produtiva oligopólios e cartéis, os medicamentos deixam de chegar até quem necessita (e os mais necessitados são, seguramente, os pobres) para ser uma regalia dos mais abastados. O próprio papel do estado, como instância intermediária entre as empresas produtoras e distribuidoras de medicamentos e o público usuário, passa a ser comprometido e até inviabilizado pelo custo dos remédios faturados pelos donos das grandes indústrias farmacêuticas, sobretudo nos países de economia periférica. $\mathrm{O}$ exemplo do Brasil é bem ilustrativo desta observação. $\mathrm{O}$ Ministério da Saúde dispõe de um orçamento anual de pouco mais de 20 bilhões de reais para cuidar de medidas de promoção, proteção e recuperação da saúde da população do país. No entanto, somente o mercado de medicamentos movimentou, no ano 2000, mais de 22 bilhões de reais. E isto sem contabilizar, logicamente, a demanda reprimida pelas restrições dos orçamentos públicos e domésticos.

Tranqüilamente, esses 22 bilhões de reais poderiam ser reduzidos pela metade, não fossem os 
preços cumulativos que incidem em cascata sobre a mercadoria medicamentos. Marcas de fantasia, valorizadas meramente pela imagem de marketing, ganham, pelo simples nome de apresentação, montantes que resultam em diferenças de preços de 50 a 100 por cento. Já os genéricos podem ser comprados com custo 30 a $40 \%$ inferior aos produtos farmacêuticos consagrados pelo mercado, mesmo se sabendo que também sofrem o ônus do processo produção/distribuição/varejo. Apenas nesta etapa (varejo) o cálculo para o preço final incorpora uma margem de lucro em torno de $30 \%$. É um comportamento mercadológico atípico, quando comparado com outros produtos, resultando no fato de que os usuários (a clientela dos serviços de saúde) ficam expostos à livre vontade das grandes indústrias farmacêuticas, a esta altura compondo empresas que cobrem muitos países e continentes.

A posição da Organização Nações Unidas, sancionando uma demanda da Organização Mundial da Saúde e, sobretudo, dos países de economia marginal da África, Ásia e América Latina, libera a população e os governos das restrições impostas unilateralmente pelos interesses convencionais da indústria e comércio de medicamentos. É uma declaração de princípios que, de fato, contribui para que os vários consensos assumidos em convenções internacionais possam, finalmente, ser incorporados aos direitos efetivos de cidadania, independentemente de fronteiras geopolíticas e de status econômico. 